\title{
Research on the Ideological and Political Construction of the Course 'Introduction to Social Security'
}

\author{
Zhang Yanli ${ }^{1}{ }^{*}$ Wang Feng ${ }^{2}$ \\ ${ }^{1}$ School of public management, Shandong Technology and Business University, Yantai, Shandong 264005, China \\ ${ }^{2}$ School of law, Shandong Technology and Business University, Yantai, Shandong 264005, China \\ *Corresponding author. Email: yanlizh6565@163.com
}

\begin{abstract}
The teaching reform of ideological and political curriculum is a strategic measure to carry out the Guiding Outline of Ideological and political Curriculum's Construction in Colleges and Universities issued by the Ministry of Education in order to realize the fundamental task of 'Establishing Morality and Cultivating Talents'. The reform of ideological and political teaching of 'Introduction to Social Security' requires that the theoretical contribution of Marxist thought to social security system should be deeply explored. Positively affirms the achievements of China's social security system and its institutional superiority; Rationally view and evaluate the social security system of western countries; Innovating ideological and political teaching methods; Combining professional teaching results with ideological and political education results, establishing evaluation feedback mechanism of the ideological and political curriculum, giving full play to educational function.
\end{abstract}

Keywords: The Course of Introduction to Social Security, the Ideological and Political Construction, Teaching Reform.

\section{INTRODUCTION}

The General Office of the CPC Central Committee and The State Council issued opinions on Deepening the Reform and Innovation of Ideological and Political Theory Courses in Schools in the New Era on August 14, 2019. On May 28, 2020, in order to thoroughly implement General Secretary Xi Jinping's important discourse on education and the spirit of the National Education Conference, the Ministry of Education in China issued the Guiding Outline for Ideological and Political Construction of College Courses, aiming to put ideological and political education through the talent training system and comprehensively promote ideological and political construction of college courses. As the core course of labour and social security major in colleges and universities, it is urgent to integrate ideological and political elements into the teaching design to guide students to enhance their national pride and patriotic enthusiasm.

\section{NECESSITY AND SIGNIFICANCE}

The course of 'Introduction to Social security' is to study the basic theory of social security and its practical activities and development rules. It is one of the required courses for labour and social security majors. The major of Labour and Social Security belongs to the discipline of Public Administration and is committed to training talents for the public administration of Chinese government. As government public administrators, in addition to the necessary strong professional skills and management level, the first thing is to be loyal to socialism with Chinese characteristics, must resolutely support the leadership of the Communist Party of China. Therefore, it is necessary to thoroughly implement curriculum ideology and politics in the curriculum system and teaching contents of labour and social security and strive to train the young to shoulder the great responsibility of national rejuvenation, and cultivate socialist builders [1]. Through the reform of ideological and political teaching of the course of 'Introduction to social security', it is helpful to promote moral education and cultivate students' national pride, patriotic enthusiasm and political consciousness. 


\subsection{A Necessary Way to Promote Patriotism Education and Enhance Students' Self- confidence}

Since the 18th National Congress of the Communist Party of China (CPC), China has built the world's largest social security system, completing in a very short time what developed countries have done for more than 100 years. The 1.4 billion Chinese people are protected against risks such as illness, old age, work-related injury, disability and poverty. Especially during the pierid of COVID-19, China took the lead in bringing the epidemic under control and quickly recovering the economy. In the past, it was generally believed that European and American countries had a high level of science and technology, advanced medical technology, medical security and emergency response capacity. However, the failure of European and American countries to respond to COVID-19 has exposed the shortcomings and inadequacies of their public health and healthcare systems. In the process of narrating the chapter of public health and medical insurance of the course of 'Introduction to Social security', through the comparison between China and the West, it can enhance students' confidence in the road, theory, system and culture of socialism with Chinese characteristics, and improve their national pride and patriotic enthusiasm.

\subsection{A Strategic Measure to Implement the Fundamental Task of Moral Education}

A country without virtue is not prosperous, and a person without virtue is not a good man. The foundation of education lies in virtue casting soul. In the teaching process of social assistance section of the course of 'Introduction to Social Security', reviews the development of Chinese social assistance history, from the Confucianism to Xi Jinping Thought on Socialism with Chinese Characteristics for a New Era, these undoubtedly demonstrate the traditional virtues of the Chinese nation, such as helping the needy, respecting the old, caring for the baby, helping the weak and the disabled and so on. President Xi Jinping has pointed out, not one of them should be left behind on the way to an all-round well-off society in China.

\subsection{An Important Task to Improve the Quality of Personnel Training}

The essence of competition between countries is the competition of science and technology and talents. Colleges and universities are the cradle of cultivating senior specialized talents. However, a person with moral and professional skills can be called a talent. 'Efforts should be made to build an education system that comprehensively cultivates talents with morality, wisdom, health, kindness, diligence, and form a higherlevel talent training system,' Present $\mathrm{Xi}$ said. It is necessary to integrate moral education, cultural knowledge education and social practice education into all aspects of basic education, vocational education and higher education. Discipline system, teaching system, textbook system and teaching management system should be designed around this goal. Since the 18th CPC National Congress, Present Xi Jinping has made a series of important statements on 'cultivating socialist builders and successors' and answered the questions such as 'Who to train? For whom to train? How to train? [2]' On March 18, 2019, in the ideological and political theory course in school teacher symposium, Present Xi Jinping further stressed that 'To lead the Chinese people to China's great future, the $\mathrm{CPC}$ must cultivate generations of talented people who are determined to devote themselves to the cause of socialism with Chinese characteristics under the leadership of the CPC.' To sum up, colleges and universities should make overall plans for the construction of ideological and political courses, integrate construction of the ideological and political curriculum into the teaching system and content system of professional courses, and make college students become socialist builders and successors.

\section{KEY POINTS OF IDEOLOGICAL AND POLITICAL TEACHING REFORM}

\subsection{Deeply Excavate the Contribution of Marxism to Social Security Discipline in China.}

Marxism laid a solid ideological foundation for Chinese social security disciplines. We should combinate Marxist theory and China actual experience. Push China are more fairness, more justice, more shared, more sustainable and healthy development [3]. During the teaching the course of 'Introduction to Social security', we should emphasis Marxist theory, Present $\mathrm{Xi}$ Jinping Thought on Socialism with Chinese Characteristics for a New Era. We should emphasise that Chinese government always safeguards and improves people's livelihood, maintaining social justice, and improves people's well-being, and promotes the reform of social security system, and finally promotes the development of social security in China.

\subsection{Positive Affirmation of China's Social Security System Has Made Achievements and Reflected the System Superiority.}

While correctly understanding the problems of social security system of China, we should also affirm the achievements of China's social security system since the founding of the People's Republic of China and its institutional superiority. For example, chapter I emphasizes the development concept of fairness, justice 
and sharing behind the practice of China's social security system and the superiority of the socialist system reflected in it. Chapter II, the development of social security System, emphasizes the differences in cognition and orientation of social security between China and the West, and the differences in practice paths of social security system reflected by them. Chapter III , social security theories emphasize that Marxism has laid the ideological foundation for social security discipline in China. Chapter IV, social security rule by law and management, the achievements of China's social security legislation are emphasized. Chapter V , social security fund, emphasizes that China's financial subsidies to social security fund, highlighting the government's responsibility.

\subsection{Rationally View and Correctly Evaluate the Social Security System of Western Countries.}

Abandon the blind worship and flattery of the social security system of western countries. In the past few decades, China and western countries have been quite different in terms of science, technology and economic development. And the West has long dominated international opinion. In addition, many scholars do not have the practical experience of field investigation in western countries, so they just conduct literature research. Therefore, in some media, we have seen excessive affirmation and worship of the policy effect and practical experience of the social security system in western countries. Therefore, in the past, in the teaching the courses of 'Introduction to social security' in colleges and universities, there is also excessive recognition of the social security practice experience of western countries. Of course, the successful experience of social security system in western countries should also be treated rationally and dialectically.

\subsection{Innovating Ideological and Political Teaching Methods.}

First of all, combined with the characteristics of college students often surfing the Internet and using APPs on their phones, we should use a variety of teaching methods such as class network teaching means, mix online and offline activities, social practice and virtual simulation experiments. So let students participate in and better be immersed in classroom teaching. Secondly, we should combine with the characteristics of college students' widespread attention to international and domestic social hot news, use cases analysis, heuristic teaching method, role playing teaching method, brainstorming method, intuitive demonstration method, to guide college students to use social security basic theory to analyse the practice of social security system.

\section{PROBLEMS NEEDING ATTENTION}

\subsection{College is the Key of the Ideological and Political Construction.}

As the main place for personnel training, colleges and universities undertake the task of 'Who to train? For whom to train? How to train?' Issued by Ministry of Education, colleges and universities should actively implement the 'Institutions of Higher Learning Education Course Construction Guidelines'. Colleges and universities should attach great importance to and promote the ideological and political construction of curriculum. Colleges and universities should take various measures to mobilize the enthusiasm of teachers to participate in the construction of the ideological and political curriculum, promote the construction of ideological and political curriculum according to the characteristics of the specialty, amend the talent training plan and teaching content, and integrate construction of the ideological and political curriculum into the whole process of classroom teaching. In addition, colleges and universities should establish and perfect the quality evaluation system and incentive mechanism of ideological and political construction, strengthen the organization and implementation of ideological and political construction and guarantee the conditions.

\subsection{Teachers are the Main Force of the Ideological and Political Construction.}

The implementation effect of the ideological and political curriculum mainly depends on teachers' own political consciousness and cognitive level of the ideological and political curriculum. Therefore, the ideological and political construction requires teachers to have firm Marxist beliefs and political literacy. We should correctly recognize the significance of the ideological and political construction for the realization of national talent development strategy.

\subsection{Curriculum Construction is the Front of the Ideological and Political Construction.}

Construction the ideological and political curriculum is a systematic project. Colleges and universities should carry out construction from the aspects of talent training program, specialty construction, curriculum setting, compilation and selection of teaching materials, compilation of teaching plans and courseware, construction of teaching staff and so on [4]. In the process of practice, we should gradually promote the ideological and political construction reform and accumulate experience in the ideological and political construction reform by means of setting up educational reform projects, teaching competitions and observing classes, and gradually improve the teaching reform materials of the ideological and political curriculum. 


\subsection{Students are Not Only the Direct Object of the Ideological and Political Curriculum, But Also the Direct Embodiment of Ideological and Political Effect.}

Contemporary college students are active in thinking, willing to express, and have strong ability to accept new things. However, they are also prone to be misled by some media and have extreme views on some social issues. They are easily confused, and their critical thinking skills need to be improved, which is in urgent need of guidance. Teachers should approach college students, deeply understand the characteristics of contemporary college students, innovate teaching methods and explore ideological and political materials from the contact with students [5]. Through the course ideological and political identity, strengthen college students' political identity, ideological identity and cultural identity, improve the political literacy of college students.

\section{CONLUSIONS}

In a word, to construct the ideological and political curriculum is the necessary way to promote patriotism education and enhance students' Four Self-confidence. The ideological and political construction is the strategic measure to implement the fundamental task of moral education and the important task of improving the quality of personnel training comprehensively. The reform of ideological and political teaching the course of 'Introduction to Social Security' focuses on deeply excavating the theoretical contribution of Marxism, positively affirming the achievements of China's social security system and its institutional superiority, rationally viewing and evaluating the social security system of western countries, innovating ideological and political teaching methods, combining professional teaching results with ideological and political education results, forming a good evaluation feedback mechanism of the ideological and political curriculum. In the course of the ideological and political construction, attention should also be paid to the following aspects: universities are the key of the ideological and political construction, teachers are the main force of the ideological and political construction, curriculum construction is the front of the ideological and political construction, and students are the direct object of the ideological and political construction. Under the correct guidance and promotion of colleges and universities, under the higher cognitive level and political awareness of course teachers, and under the active participation and close cooperation of college students, the level and effect of course ideology and politics should be improved. And it'll finally implement Present Xi Jinping's important discussion on education, the spirit of the National Education Conference and the Guidance Outline for Ideological and Political Construction of Higher
Education Curriculum issued by the Ministry of Education of China.

\section{ACKNOWLEDGMENT}

This work was supported by the Ministry of Education Humanities and Social Sciences Research Youth Foundation (16YJC820033), Teaching Reform Project of Shandong Technology and Business University (11688202004) and Doctor Funds Project of Shandong Technology and Business University (BS201807).

\section{REFERENCES}

[1] HONG Dandan, WANG Xiaojie, NING Nan, Research on the Ideological and Political Construction of the Course 'Introduction to Social Security', Innovation and Entrepreneurship Theory research and Practice, No. 4, Feb. 2020.

[2] ZHANG Shuo, Xi Jinping, Cultivating socialist Builders and successors with all-round development of Morality, Intelligence, Physique, Beauty and labour, Overseas edition of People's Daily, Edition No.2. Sep. 11,2018.

[3] DENG Qiuliu, DENG Qiuzhi, Exploring the application of heuristic teaching method in the ideological and political reform of social security curriculum, Education and Teaching Forum, Apr.2020. No. 17.

[4] HU Zemin, ZHU Shuai ling, QIN Jing Zhi, ZHONG Jie, China Education News, Edition No.8. Sep. 24,2020

[5] ZHOU Juan, On the Reform of 'Curriculum Ideology and Politics' in Sociology under the 'Family-country Sentiment', Education Teaching Forum, Nov. 2020. No. 48 